УДК 349.22

DOI https: / / doi.org/10.32837 / yuv.v0i6.2060

\author{
Я. Мельник, \\ аспірант кафедри трудового права \\ Національного юридичного університету імені Ярослава Мудрого
}

\title{
ОПЛАТА ПРАЦІ: ПРАВОВИЙ АСПЕКТ
}

Постановка проблеми. Забезпечення стабільного економічного розвитку України та підвищення життевого рівня населення тісно пов'язане з проведенням ефективної політики у сфері регулювання оплати праці. На сучасному етапі спостерігається надто низький рівень реальної заробітної плати, наявність заборгованості з іï виплати. Заробітна плата $€$ основним джерелом доходів працівників і найсильнішим мотиватором розвитку трудового потенціалу більшості населення, але останнім часом вона не виконує свої функції. Відсутність системного підходу держави до вирішення проблем стимулювання високопродуктивної праці унеможливлює економічне зростання, стабілізацію і підвищення рівня життя населення. Тільки через оплату праці та вдосконалення механізму іï регулювання можна рухатися вперед шляхом прогресу та процвітання України.

Актуальність дослідження. Дослідженням проблем оплати праці присвячені праці таких науковців, як B.M. Божко, В.M. Вегера, О.В. Гаєвая, С.Ю. Головіна, І.В. Зуб, Г.А. Капліна, А.М. Колот, Р.3. Лівшиць, В.І. Прокопенко, О.І. Процевський, В.Г. Ротань, К.О. Севастьяненко, О.А. Соколова, Б.С. Стичинський, О.М. Ярошенко та ін. Втім, незважаючи на існування чималої кількості теоретичних i емпіричних напрацювань науковців у сфері оплати праці, не всі аспекти зазначеної проблематики розроблені повною мірою. Зокрема, реалії сьогодення потребують поглибленого вивчення й уточнення сутності оплати праці як правової категорії з ураху- ванням іï специфіки в різних галузях, оскільки економічні процеси, які нині відбуваються в країні, докорінно змінюють теоретичні погляди на сутність оплати праці як правової категорії.

Метою статті $€$ узагальнення теоретичних поглядів на сутність оплати праці як правової категорії, на підставі чого зробити певні висновки.

Виклад основного матеріалу. Як зазначає B.I. Прокопенко, є два аспекти заробітної плати: економічний і правовий. 3 економічної точки зору заробітною платою вважається вартість або ціна праці в грошовій формі як частка працівника в національному доході, що на еквівалентній основі виплачується йому за виконану роботу. Юридичною категорією заробітна плата стає тоді, коли правовими нормами визначаються розмір і порядок iï виплати за виконану роботу. Для правового визначення заробітної плати має значення обов'язок роботодавця виплачувати працівникові винагороду за його працю, з одного боку, i наявність у працівника суб'єктивного права на одержання цієї винагороди за попередньо встановленими нормами праці - з іншого. Політика винагороди за працю організовується так, щоб свідома ініціатива працівників була спрямована на підвищення продуктивності праці, вдосконалення своєї кваліфікаціі, давала працівнику змогу своєю працею збільшувати свій трудовий дохід [1, с. 326].

На переконання М.А. Бочарова, правовий аспект оплати праці випливає із суті права як сукупності загальнообов'язкових норм, охоронюваних силами держави. Правовий аспект - 
це закріплення в нормах права гарантій, меж, умов досягнутого компромісу сторін у допустимому вигляді, об'ємі, напрямах [2, с. 15-17].

Розглядаючи оплату праці як правову категорію, можна виокремити два ї̈ аспекти. По-перше, як правова категорія, оплата праці розкриває конкретні права й обов'язки учасників трудових правовідносин із приводу оплати праці. Вона $€$, із цієї точки зору, однією з істотних умов трудового договору. По-друге, оплата праці $€$ інститутом галузі трудового права, являючи собою систему юридичних норм, що регулюють відносини у сфері організації оплати праці [3, с. 406]. Як зазначає С.С. Каринський, при визначенні заробітної плати як правової категорії основна увага приділяється тій стороні цього багатогранного поняття, яке характеризує наявні між працівником і роботодавцем правовідносини з оплати праці, що є частиною основного складного трудового правовідношення, яке існує між тими ж сторонами [4, с. 22].

На думку М.В. Філіппової й Е.Б. Хохлова, заробітна плата як правова категорія являє собою обов'язок роботодавця надати працівникові винагороду за працю залежно від кваліфікації працівника, складності, кількості, якості та умов виконуваної роботи в установленому трудовим договором розмірі, що виплачується в межах та в порядку, визначених законодавством, колективним договором (угодою) та трудовим договором [3, с. 408]. P.3. Лівшиць виокремлює такі основні ознаки заробітної плати як правової категоріі: 1) заробітна плата - це винагорода за кількістю та якістю праці; 2) заробітна плата - це винагорода робітників і службовців: оплата затраченої праці становить суть заробітної плати; 3) заробітна плата - це винагорода за працю протягом певного часу, таким чином, це оплата робочого часу; 4) заробітна плата - це винагорода згідно з раніше зумовленими нормами та розцінками [5, с. 12-23].
Правове регулювання оплати праці працівників, які перебувають у трудових відносинах із власником підприємств, установ та організацій всіх форм власності й видів господарювання, а також з окремими громадянами на підставі трудового договору, здійснюється Конституцією України, Кодексом законів про працю України, законами України «Про оплату праці», «Про колективні договори та угоди» та іншими нормативно-правовими актами, колективними договорами й локальними положеннями конкретних підприємств.

У нормативно-правових актах вживаються два терміни - «оплата праці» та «заробітна плата». Традиційно щодо оплати праці найманих працівників застосовується термін «заробітна плата», маючи на увазі, що грошова винагорода виплачується за виконану роботу, тобто за витрачену працю. Так, відповідно до ст. 11 Закону України «Про оплату праці» [6] заробітна плата визначається як винагорода, обчислена, як правило, у грошовому виразі, яку за трудовим договором власник або уповноважений ним орган виплачує працівникові за виконану ним роботу. Розмір заробітної плати залежить від складності та умов виконуваної роботи, професійно-ділових якостей працівника, результатів його праці та господарської діяльності підприємства. Ст. 94 КЗпП [7] передбачено важливе доповнення до цього визначення, відповідно до якого заробітна плата максимальним розміром не обмежується, що, на нашу думку, $є$ необхідною та доцільною гарантією конституційно закріпленого права на працю.

Щодо терміна «оплата праці», то нині в законодавстві немає ні чіткого його визначення, ні критеріїв розмежування означених термінів. Тобто законодавство вживає поняття «оплата праці» та «заробітна плата» як слова-синоніми, проте 3 такою позицією законодавця досить важко погодитись, оскільки науковці застерігають від застосування термі- 
нів-синонімів у праві, називаючи це одним із найпоширеніших порушень принципу єдності юридичної термінології [8, с. 114]. Означене можна пояснити тим, що в мові практично немає абсолютних синонімів, що унеможливлює ефективне правове регулювання без чіткого визначення понятійних категорій. Саме тому терміни «оплата праці», «заробітна плата» мають бути чітко визначені, розмежовані й наповнені конкретним змістом. Тому доцільно буде розглядати «оплату праці» як термін більш широкий, оскільки його цільове призначення спрямоване на організацію оплати праці, регламентацію іiі окремих елементів і всієї системи правових засобів у цій сфері, а «заробітну плату» своєю чергою - як термін, порівняно вужчий і спрямований на права працівника в трудових відносинах, отримання грошової винагороди. Зокрема, Р.3. Лівшиць вважав зміст термінів «оплата праці» та «заробітна плата» схожим, але не ідентичним, та розділяв їх за обсягом, визначаючи як ціле («оплата праці») та частину («заробітна плата»). Учений зазначав, що заробітну плату необхідно відокремити від інших форм винагороди за працю, характерних для цивільних та інших правовідносин [5, с. 7, 15]. Такої самої позиції дотримуються й деякі сучасні науковці [9, с. 13], з чим неможливо не погодитись.

Наявна і протилежна позиція в науковій думці. Так, В.Г. Ротань, І.В. Зуб та Б.С. Стичинський вважають, що з точки зору прав та обов'язків сторін трудового договору поняття «заробітна плата» й «оплата праці» є синонімами. Різниця між ними полягає лише в тому, що поняття заробітної плати акцентує на об’єкті правовідносин між працівником і власником, а категорія оплати праці - на дії власника, яку він має здійснити через наявність трудових правовідносин (оплатити працю). Виявити ж будь-які особливості прав та обов'язків, умов ї реалізації та наслідків невиконання обов'язків залежно від застосування в тому чи іншому законі або іншому нормативно-правовому акті одного 3 двох названих понять неможливо [10, c. 431].

Структура заробітної плати визначена ст. 2 Закону України «Про оплату праці» і складається 3 трьох частин: основна заробітна плата, додаткова та інші заохочувальні й компенсаційні виплати. Основна заробітна плата - це винагорода за виконану роботу відповідно до встановлених норм праці (норм часу, виробітку, обслуговування, посадових обов'язків). Вона встановлюється згідно 3 відрядними розцінками для працівників, тарифними ставками або посадовими окладами для службовців. До основної заробітної плати належать також суми процентних або комісійних нарахувань, отриманих від реалізації продукції, якщо вони є основним видом оплати праці, а також суми авторського гонорару працівникам мистецтва, редакцій газет і журналів, телеграфних агентств, видавництв, радіо, телебачення, а також оплата, що здійснюється за ставками авторської винагороди, нарахованої на відповідному підприємстві, особам, які перебувають у трудових відносинах. Додаткова заробітна плата - це винагорода за працю понад установлені законодавством, колективним чи трудовим договором норми праці, за трудові досягнення та винахідливість і за особливі умови праці. До неї належать передбачені чинним законодавством доплати й надбавки до тарифних ставок i посадових окладів: за високу кваліфікаційну майстерність; за класність; за керівництво бригадами; персональні надбавки; за високі досягнення у роботі або за виконання особливо важливих завдань; за знання іноземної мови; за суміщення професій (посад); за розширення зон обслуговування або збільшення обсягу виконуваних робіт; за роботу у важких, шкідливих, особливо шкідливих умовах, 
роботу в багатозмінному, безперервному режимі виробництва, у нічний час та ін. До додаткової заробітної плати враховуються також премії за виконання й перевиконання виробничих завдань, виконання акордних завдань, підвищення продуктивності праці, поліпшення кінцевих результатів господарської діяльності структурної одиниці, економію матеріальних ресурсів тощо. Інші заохочувальні та компенсаційні виплати встановлюються у формі винагороди за підсумками роботи за рік, премій за спеціальними системами й положеннями. Це компенсаційні та інші грошові та матеріальні виплати, які не передбачені актами чинного законодавства або які виплачуються понад установлені норми. До них належать: оплата простоїв не з вини працівника; суми оплати вимушених відпусток 3 ініціативи роботодавця 3 частковим збереженням заробітної плати; винагорода за підсумками роботи за рік; виплати працівникам, які брали участь у страйках; одноразові заохочення; матеріальна допомога; суми наданих підприємством трудових і соціальних пільг; оплата за навчання в навчальних закладах дітей працівників підприємства; вартість путівок для лікування й відпочинку; інші компенсаційні виплати. Гарантійні та компенсаційні виплати не є заробітною платою, оскільки мають інше цільове призначення. Однак, будучи включеними в єдиний організаційний та обліковий механізм, вони є складовим елементом системи організації оплати праці.

Держава через механізм централізованого регулювання забезпечує єдині правові засади оплати праці основної частини найманих працівників за такими напрямами, як установлення мінімальної заробітної плати, визначення іï структури, впровадження певних форм оплати робочої сили, індексація заробітної плати й здійснення заходів із метою запобігання іiі зростання. Як стверджують Ю. Лігум й Г. Куліков, з якими ми погоджуємося, державне регулювання оплати праці є системою визначення правил, процедур, нормативів, норм і гарантій в оплаті праці на підставі прийняття певних законодавчих і нормативних актів та контролю за їх дотриманням органами влади [11, с. 6]. Головною метою та функцією державного регулювання оплати праці визнається створення необхідних умов для забезпечення виконання оплатою праці всіх властивих їй основних функцій (відтворювальної, стимулюючої, регулюючої і соціальної).

Відповідно до ст. 8 Закону України «Про оплату праці» визначено сферу державного регулювання заробітної плати найманих працівників в Україні. На державному рівні відбувається встановлення: (а) розміру мінімальної заробітної плати; (б) інших державних норм і гарантій оплати праці; (в) умов і розмірів заробітної плати керівників підприємств, заснованих на державній, комунальній власності; (г) умов і розмірів заробітної плати працівників підприемств, установ та організацій, що фінансуються чи дотуються 3 бюджету; (г) регулювання фондів оплати праці працівників підприємств-монополістів згідно 3 переліком, що визначається Кабінетом Міністрів України; (д) оподаткування доходів працівників.

У науці трудового права існує думка, що державний вплив на оплату праці полягає, насамперед, у створенні відповідного правового поля. На сучасному етапі сукупність правових норм, спрямованих на регулювання оплати праці, потребує істотної систематизації 3 метою підвищення їх узгодженості, усунення колізійності. Як зазначає Г.А. Капліна, 3 якою ми погоджуємося, така систематизація має відбуватися шляхом об'єднання вказаних норм у межах книги «Оплата праці» нового Трудового кодексу України [12, с. 11].

Висновки. Підбиваючи підсумок вищенаведеному, варто зазначити, 
що однією із найважливіших складових частин організації діяльності будь-якого підприємства є оплата праці. Оскільки від оптимальної системи оплати праці залежить не лише життєвий рівень працівників, а й результати господарської діяльності підприємства загалом. Природа оплати праці багатогранна, оскільки для роботодавця вона виступає витратами виробництва, які зазвичай він намагається мінімізувати, а для працівника - доходом, і він, відповідно, намагається іï максимізувати, домовляючись про доволі високий рівень оплати праці. Тому правильна організація оплати праці, дотримання справедливих пропорцій, співвідношень, обліку розмірів заробітної плати з умовами й результатами праці слугують могутнім чинником стимулювання продуктивності праці, зацікавленості працівника в підвищенні результативності й якості роботи.

Як правова категорія оплата праці розкриває конкретні права й обов'язки учасників трудових правовідносин із приводу оплати праці, виступає однією 3 істотних умов трудового договору. Вона $€$ інститутом галузі трудового права, являючи собою систему юридичних норм, що регулюють відносини у сфері організації оплати праці.

У статті узагальнено теоретичні погляди на сутність оплати праці як правової категорії, на підставі чого зроблені відповідні висновки. Зазначено, що, незважаючи на існування чималої кількості теоретичних $i$ емпіричних напраиювань науковиів у сфері оплати праці, не всі аспекти зазначеної проблематики розроблені повною мірою. Зокрема, реалії сьогодення потребують поглибленого вивчення й уточнення сутності оплати праці як правової категорії з урахуванням ї̈ специфіки в різних галузях, оскільки економічні процеси, які нині відбуваються в країні, докорінно змінюють теоретичні погляди на сутність оплати праці як правової категорії.

Зроблено висновок, що як правова категорія оплата праці розкриває конкретні права й обов' язки учасників трудових правовідносин iз приводу оплатu праці, виступає однією з істотних умов трудового договору. Вона є інститутом галузі трудового права, являючи собою систему юридичних норм, що регулюють відносини у сфері організаизї оплати праці. Звернено увагу на терміни «оплата праці» й «заробітна плата», зокрема, зроблено висновок щодо їх чіткого визначення, розмежування й наповнення конкретним змістом.

У підсумку зазначено, щзо оплаma праці є одним із важливих складників організацї діяльності будь-якого підприємства, оскільки від оптимальної системи оплати праці залежить не лише життевий рівень працівників, а й результати господарської діяльності підприємства загалом. Природа оплати праці багатогранна, оскільки для роботодавия вона виступае витратами виробництва, які зазвичай він намагається мінімізувати, а для працівника - доходом, $i$ він, відповідно, намагається ї максимізувати, домовляючись про доволі високий рівень оплати праці. Тому правильна організація оплати праизі, дотримання справедливих пропориій, співвідношень, обліку розмірів заробітної плати з умовами ü результатами праці слугують могутнім чинником стимулювання продуктивності праці, зацікавленості працівника в підвищенні резульmативності й якості роботи.

Ключові слова: працівник, роботодавець, держава, оплата праці, заробітна плата, правовий аспект.

Melnik Ya. Payment of labor: legal aspects

The article summarizes the theoretical views on the essence 
of wages as a legal category, on the basis of which the relevant conclusions are made. It is noted that despite the existence of a large number of theoretical and empirical developments of scientists in the field of remuneration, not all aspects of this issue are sufficiently developed. In particular, the realities of today require in-depth study and clarification of the essence of wages as a legal category, taking into account its specifics in various fields. Because, the economic processes currently taking place in the country radically change the theoretical views on the essence of wages as a legal category.

It is concluded that as a legal category of remuneration reveals the specific rights and obligations of participants in labor relations regarding remuneration, is one of the essential conditions of the employment contract. It is an institution of labor law, representing a system of legal norms governing relations in the field of remuneration. Attention is paid to the terms "remuneration" and "wages", in particular, a conclusion is made on their clear definition, delimitation and filling with specific content.

As a result, it is noted that wages are one of the important components of the organization of any enterprise. Because the optimal system of remuneration depends not only on the living standards of employees, but also the results of economic activity of the enterprise as a whole. The nature of wages is multifaceted, because for the employer it is the cost of production, which he usually tries to minimize, and for the employee - income, and he, accordingly, tries to maximize it by agreeing on a sufficiently high level of wages. Therefore, the correct organization of wages, fair proportions, ratios, accounting for wages with working conditions and results are a powerful factor in stimulating productivity, employee interest in improving productivity and quality of work.

Key words: employee, employer, state, salary, salary, legal aspec.

\section{Література}

1. Прокопенко В.I. Трудове право: підруч. Харків : Консум, 1998. 480 с.

2. Бочаров M.A. Oплата труда в системе социальных отношений : автореф. дис. ... канд. юрид. наук : 12.00.05. Москва, 1998. 20 c.

3. Трудовое право России / под ред. С.П. Маврина, Е.Б. Хохлова. Москва : Юрuсть, 2002. 560 c.

4. Каринский С.С. Правовое регулирование заработной плать. Москва: Юрид. rum., 1963. 212 c.

5. Лившиц Р.3. Заработная плата в СССР. Правовое исследование / отв. ред. C.А. Иванов. Москва: Наука, 1972. 271 с. 6. Про оплату праці: З Закон України від 24.03.1995 р. № 108/95-BP. Відомості Верховної Ради України. 1995. № 17. Cm. 121 .

7. Кодекс законів про працю України : Закон УРСР віО 10.12.1971 р. № 322-VIII. Відомості Верховної Ради УРСР. 1971. Дод. до № 50. Сm. 375.

8. Язык закона / под ред. А.С. Пиголкина. Москва: Юрид. лит., 1990. 328 с.

9. Божко В.М. Колективно-договірне регулювання заробітної плати : дис. ... канд. юрид. наук : 12.00.05. Харків, 2002. 203 c.

10. Науково-практичний коментар до законодавства України про пращю / В.Г. Pomaнь, I.В. Зуб, Б. Стичинський. 6-те вид., доп. і переробл. Київ : A.C.К., 2005. $976 \mathrm{c}$.

11. Лігум Ю., Куліков Г. Удосконалення державного регулювання оплати праці. Україна: аспекти праці. 2000. № 2. C. 6-9.

12. Капліна Г.А. Проблеми правового регулювання оплати праці в ринкових умовах України $і$ шляхи іх вдосконалення : автореф. дис. ... канд. юрид. наук : 12.00.05. Харків, 2009. 20 c. 